\title{
PEMBIAYAAN MURABAHAH DALAM PERSPEKTIF FIQH ISLAM, HUKUM POSITIF DAN HUKUM SYARIAH
}

\section{Tri Setiady}

Fakultas Hukum Universitas Wiralodra Indramayu

\begin{abstract}
Murabaha financing. Murabaha is an agreement of sale and purchase between the two parties, in which the buyer and seller agree on the sale price; which consists of purchase price plus purchase costs and profits for sellers. Another understanding of Murabaha is an agreement of sale and purchase by declaring the acquisition cost and the benefits agreed upon by the seller and buyer. Murabaha can be made in cash, or also pay in installments. Another understanding of Murabaha is a sale and purchase transactions, which is the bank received a number of advantages. In this case, the bank become a seller and customers into buyers.
\end{abstract}

Keywords: Murabaha Financing, Positive Law and Sharia Law

\section{abstrak}

Pembiayaan murabahah. Murabahah adalah akad jual beli antara dua belah pihak, dimana pembeli dan penjual menyepakati harga jual, yang terdiri atas harga beli ditambah ongkos pembelian dan keuntungan bagi penjual. Pemahaman lain murabahah adalah akad jual beli barang dengan menyatakan harga perolehan dan keuntungan (margin) yang disepakati oleh penjual dan pembeli. Murabahah dapat dilakukan secara tunai, bisa secara bayar tangguh atau bayar dengan angsuran. Pemahaman lain murabahah adalah transaksi jual beli, dimana bank mendapat sejumlah keuntungan. Dalam hal ini, bank menjadi penjual dan nasabah menjadi pembeli.

\section{Kata Kunci: Pembiayaan Murahabah, Hukum Positif, Hukum Syariah}

\section{A. Pendahuluan}

Sebagaimana diamanatkan oleh Pancasila dan Undang-Undang Dasar Negara Republik Indonesia Tahun 1945, tujuan pembangunan nasional adalah terciptanya masyarakat adil dan makmur, berdasarkan demokrasi ekonomi, dengan mengembangkan sistem ekonomi yang bertumpu pada mekanisme pasar yang berkeadilan. Guna mewujudkan tujuan tersebut, pelaksanaan pembangunan ekonomi nasional diarahkan pada perekonomian yang berpihak pada ekonomi kerakyatan, merata, mandiri, handal, 
berkeadilan, dan mampu bersaing di kancah perekonomian internasional. Sebagaimana diamanatkan oleh Pancasila dan Undang-Undang Dasar 1945.

Agar tercapai tujuan pembangunan nasional dan dapat berperan aktif dalam persaingan global yang sehat, diperlukan partisipasi dan kontribusi semua elemen masyarakat untuk menggali berbagai potensi yang ada di masyarakat guna mendukung proses akselerasi ekonomi dalam upaya merealisasikan tujuan pembangunan nasional. Salah satu bentuk penggalian potensi dan wujud kontribusi masyarakat dalam perekonomian nasional tersebut adalah pengembangan sistem ekonomi berdasarkan nilai Islam (Syariah) dengan mengangkat prinsip-prinsipnya ke dalam Sistem Hukum Nasional. Prinsip Syariah berlandaskan pada nilai-nilai keadilan, kemanfaatan, keseimbangan, dan keuniversalan (rahmatan lil 'alamin). Nilai-nilai tersebut diterapkan dalam pengaturan perbankan yang di dasarkan pada Prinsip Syariah yang disebut Perbankan Syariah.

Dewasa ini kerangka hukum bank syariah telah diatur secara khusus dan tersendiri dalam Undang-Undang Nomor 21 Tahun 2008 tentang Perbankan Syariah. Pembentukan Perbankan Syariah ini di dasarkan pada pertimbangan bahwa perlunya aturan spesifik atau khusus dalam suatu undang-undang tersendiri yang mengatur perbankan syariah, berhubungan perbankan syariah memiliki kekhususan dibandingkan dengan perbankan konvensional dan kebutuhan masyarakat indonesia akan jasa-jasa perbankan syariah semakin meningkat. Sejalan dengan itu, sesuai dengan tujuan pembangunan nasional Indonesia untuk mencapai terciptanya masyakat yang adil dan makmur berdasarkan demokrasi ekonomi, maka dikembangkan sistem ekonomi yang berlandaskan pada nilai keadilan, kebersamaan, pemerataan, dan kemanfaatan yang sesuai dengan prinsip syariah dengan mengangkatnya ke dalam sistem hukum nasional.

Guna menjamin kepastian hukum bagi stakeholders dan sekaligus memberikan keyakinan kepada masyarakat dalam menggunakan produk dan jasa Bank Syariah, dalam Undang-Undang Perbankan Syariah ini diatur jenis usaha, ketentuan pelaksanaan syariah, kelayakan usaha, penyaluran dana, dan larangan bagi Bank Syariah maupun UUS yang merupakan bagian dari Bank Umum Konvensional. Sementara itu, untuk memberikan keyakinan pada masyarakat yang masih meragukan kesyariahan operasional Perbankan Syariah selama ini, diatur pula kegiatan usaha yang tidak bertentangan dengan Prinsip Syariah meliputi kegiatan usaha yang tidak mengandung unsur-unsur riba, maisir, gharar, haram, dan zalim, yang pelaksanaannya dilakukan secara menyeluruh (kaffah) dan konsisten (istiqomah). Pengelolaan bank syariah juga berpedoman pada prinsip kehati-hatian guna mewujudkan perbankan syariah yang sehat, kuat, dan efisien sesuai dengan ketentuan peraturan perundang-undangan. 
Sebagai undang-undang yang khusus mengatur perbankan syariah, dalam Undang-Undang ini diatur mengenai masalah kepatuhan syariah (syariah compliance) yang kewenangannya berada pada Majelis Ulama Indonesia (MUI) yang direpresentasikan melalui Dewan Pengawas Syariah (DPS) yang harus dibentuk pada masing-masing Bank Syariah dan UUS. Untuk menindaklanjuti implementasi fatwa yang dikeluarkan MUI ke dalam Peraturan Bank Indonesia, di dalam internal Bank Indonesia dibentuk komite perbankan syariah, yang keanggotaannya terdiri atas perwakilan dari Bank Indonesia, Departemen Agama, dan unsur masyarakat yang komposisinya berimbang.

Bank Islam atau bank syariah adalah lembaga keuangan yang usaha pokoknya memberikan kredit dan jasa-jasa lain dalam lalu lintas pembayaran serta peredaran uang yang pengoperasiannya disesuaikan dengan prinsip syariat Islam. Dalam ketentuan Pasal 1 angka 13 Undang-Undang Nomor 7 Tahun 1992 sebagaimana telah dirubah dengan Undang-Undang Nomor 10 Tahun 1988 telah dirumuskan pengertian prinsip syariah tersebut, yaitu:

"Prinsip syariah adalah aturan perjanjian berdasarkan hukum Isalm anatara bank dengan pihak lain untuk menyimpan dana dan atau pembiayaan kegiatan usaha, atau kegiatan lainnya yang dinyatakan sesuai dengan syariah, antara lain prinsip bagi hasil (mudharabah), pembiyaan berdasarkan prinsip penyertaan modal (musyarakah), prinsip jual beli barang dengan keuntungan (murabahah), atau pembiayaan barang modal berdasarkan prinsip sewa murni tanpa pilihan (ijarah) atau dengan adanya pilihan pemindahan kepemilikan atas barang yang disewa dari pihak bank oleh pihak lain (ijarah wa iqtina)".

Sementara itu, dalam Pasal 1 angka 12 Undang-Undang Nomor 21 Tahun 2008 telah dirumuskan pula pengertian prinsip syariah,yaitu:

"Prinsip syariah adalah prinsip hukum Islam dalam kegiatan perbankan berdasarkan fatwa yang dikeluarkan oleh lembaga yang memiliki kewenangan dalam penetapan fatwa di bidang syariah".

Kalau kita lihat dan kita baca ketentuan diatas, pengaturan hanya terfokus dalam hal kegiatan penyaluran dana (lending). Akan tetapi, jika ditafsirkan secara sistematis mengenai penghimpunan dana (funding), juga sudah diatur di dalamnya. Artinya, baik dalam kegiatan penghimpunan dana maupun penyaluran dana serata pelayanan jasa lainnya bagi bank syariah harus mendasarkan pada aturan perjanjian (tertulis/akad) menurut hukum Islam atau sesuai dengan syariah sebagaimana difatwakan oleh lembaga yang memiliki kewenangan dalam menetapkan fatwa di bidang syariah, yaitu DSN MUI. Dahulu dengan memedomani fatwa DSN MUI tersebut kemudian disusun ketentuan persyaratan minimum akad penghimpunan dan penyaluran dana bagi bank yang melaksanakan kegiatan usaha berdasarkan 
pinsip syariah, sebagaimana termuat dalam Peraturan Bank Indonesia Nomor 7/46/PBI/2005 tentang Akad Penghimpunan dan Penyaluran Dana bagi bank yang melaksanakan Kegiatan Usaha Berdasarkan Prinsip Syariah.

Dalam ketentuan Pasal 2 Peraturan Bank Indonesia Nomor 7/46/PBI/2005 ditegaskan bahwa dalam melaksanakan kegiatan penghimpunan dana dan penyaluran dana, bank syariah wajib membuat akad sesuai dengan ketentuan dalam Peraturan Bank Indonesia dan wajib dilaksanakan jenis transaksi syariah yang digunakan, yaitu wadi'ah, mudharabah, musyarakah, murabahah, salam, istishna, ijarah, dan qardh.

Dalam penulisan ini, penulis akan membahas mengenai pembiayaan murabahah. Murabahah adalah akad jual beli antara dua belah pihak, dimana pembeli dan penjual menyepakati harga jual, yang terdiri atas harga beli ditambah ongkos pembelian dan keuntungan bagi penjual. Pemahaman lain murabahah adalah akad jual beli barang dengan menyatakan harga perolehan dan keuntungan (margin) yang disepakati oleh penjual dan pembeli. Murabahah dapat dilakukan secara tunai, bisa secara bayar tangguh, atau bayar dengan angsuran. Pemahaman lain murabahah adalah transaksi jual beli, di mana bank mendapat sejumlah keuntungan. Dalam hal ini, bank menjadi penjual dan nasabah menjadi pembeli.

Murabahah merupakan produk perbankan Islam dalam pembiayaan pembelian barang lokal maupun internasional. Pembiyaan ini mirip dengan kredit modal kerja dari bank konvensional karena itu jangka waktu pembiyaan tidak lebih dari satu tahun. Bank mendapatkan keuntungan dari harga barang yang atas nama nasabahnya dan menambahkan suatu mark up sebelum menjual barang itu kepada atas dasar cost-plus profit. Murabahah merupakan transaksi jual beli barang antara bank dan nasabah, barang yang dibeli berfungsi sebagai agunan. Harga barang dalam perjanjian murabahah dibayar nasabah secara (cicilan). Kepemilikan beralih secara proposional sesuai dengan cicilan yang telah dibayar. Tambahan biaya (keuntungan) bagi bank dirundingkan dan ditentukan di muka antara bank dan nasabah. Dari uraian di atas maka timbul beberapa pertanyaan, yaitu 1) ketentuan pembiayaan murabahah berdasarkan perspektif fiqh?; 2) bagaimana ketentuan pembiayaan murabahah berdasarkan hukum positif?; dan 3) bagaimana ketentuan pembiayaan murabahah berdasarkan Fatwa Nomor 04/DSN-MUI/IV/2000 Jo Komplikasi Hukum Ekonomi Syariah?

\section{B. Pembahasan \\ 1. Pembiayaan Murabahah Berdasarkan Perspektif Fiqh}

Berbicara tentang murabahah, maka tidak akan dapat dilepaskan dengan sistem jual beli yang dalam figh biasa disebut dengan al-bai'. Ditinjau dari segi harga, al-bai' dapat dikategorikan menjadi beberapa bagian, di antaranya adalah murabahah. Jual beli dalam terminologi fiqh 
disebut dengan al-bai' yang secara etimologis dapat diartikan dengan (tukar menukar) atau (menukar sesuatu dengan sesuatu yang lain) atau (mengeluarkan benda yang dimiliki dengan suatu pengganti). Lafadz al-bai' dalam bahasa Arab terkadang digunakan untuk pengertian lawannya, yaitu kata asy-syira (beli). Dengan demikian kata al-bai' berarti jual, tetapi sekaligus juga berarti beli.

Secara etimologis, murabahah berasal dari mashdar yang berarti "keuntungan, laba, faedah". Wahbah az-Zuhaili memberikan definisi murabahah adalah jual beli dengan harga awal ditambah keuntungan. Murabahah tidak mempunyai rujukan atau refrensi langsung dari

Al-Qu'ran maupun Sunnah, yang ada hanyalah referensi tentang jual beli atau perdagangan. Jual beli murabahah hanya dibahas dalam kitab-kitab fiqh. Imam Malik dan Imam Syafi'i mengatakan bahwa jual beli murabahah itu sah menurut hukum walaupun Abdullah Saeed mengatakan bahwa pernyataan ini tidak menyebutkan referensi yang jelas dari Hadits.Menurut al-Kaff, seorang kritikus kontemporer tentang murabahah, bahwa para fuqaha terkemuka mulai menyatakan pendapat mereka mengenai murabahah pada awal abad ke-2 H. Karena tidak ada acuan langsung kepadanya dalam Al-Quran atau dalam Hadits yang diterima umum, maka para ahli hukum harus membenarkan murabahah berdasarkan landasan lain. Malik mendukung validitasnya dengan acuan pada praktek orang-orang Madinah. Ia berkata "Penduduk Madinah telah berkonsensus akan legitimasi orang yang membeli pakaian di sebuah toko dan membawanya ke kota lain untuk dijual dengan adanya tambahan keuntungan yang telah disepakati. Imam Syafi'i menyatakan pendapatnya bahwa jika seseorang menunjukkan sebuah komoditi kepada seseorang dan berkata

"Belikan sesuatu untuku dan aku akan memberimu keuntungan sekian dan orang itu kemudian membelikan sesuatu itu untuknya, maka transaksi demikian ini adalah sah".

Wahbah az-Zuhaili mengatakan bahwa dalam jual beli murabahah itu disyaratkan beberapa hal, yaitu :

a. mengetahui harga pokok.

Dalam jual beli murabahah disyaratkan agar mengetahui harga pokok atau harga asal, karena mengetahui harga merupakan syarat sah jual beli. Syarat ini juga diperuntukan bagi jual beli at-tauliyyah dan al-wadhi'ah;

b. mengetahui keuntungan.

Hendaknya margin keuntungan juga diketahui oleh pembeli, karena margin keuntungan tersebut termasuk bagian dari harga. Sedangkan mengetahui harga merupakan syarat sah jual beli; dan

c. harga pokok merupakan sesuatu yang dapat diukur, dihitung dan ditimbang, baik pada waktu terjadi jual beli dengan penjual dengan penjual yang pertama atau setelahnya. 
Jual beli murabahah merupakan jual beli amanah, karena pembeli memberikan amanah kepada penjual untuk memberitahukan harga pokok barang tanpa bukti tertulis. Atau dengan kata lain dalam jual beli tidak diperbolehkan berkhianat. Allah SWT berfirman dalam surah Al-Anfal 27:

"Hai orang-orang yang beriman, janganlah kamu mengkhianati Allah dan Rasul-Nya, dan janganlah kamu mengkhianati amanat-amanat yang dipercayakan kepadamu, sedang kamu mengetahui".

Berdasarkan ayat di atas, maka apabila terjadi jual beli murabahah dan terdapat cacat pada barang, maka dalam hal ini ada dua pendapat ulama fiqh, yaitu: menurut ulama Hanafiyyah, penjual tidak perlu menjelaskan adanya cacat pada barang, karena cacat itu merupakan bagian dari harga barang tersebut Sementara Jumhur ulama tidak membolehkan menyembunyikan cacat barang yang dijual karena hal itu termasuk khianat.

Ada beberapa pendapat ulama mengenai praktek murabahah di perbankan syari'ah, antara lain :

a. murabahah ini bukan jual beli melainkan hilah dengan tujuan mengambil riba;

b. murabahah merupakan jual beli inah yang diharamkan Islam;

c. murabahah merupakan bai'atani fi bai'ah; dan

d. murabahah merupakan jual beli barang yang belum dimiliki.

Pendapat pertama: murabahah bukanlah jual beli melainkan hilah dengan tujuan untuk mengambil riba. Ada sebagian ulama berpendapat bahwa tujuan murabahah adalah untuk memperoleh riba dan menghasilkan uang sebagaimana yang dilakukan oleh bank-bank konvensional. Gambarannya sebagai berikut, Secara hakiki, pembeli datang ke bank untuk mendapatkan uang pinjaman dan bank tidak membeli barang (asset) kecuali dengan maksud untuk menjual kepada pembeli secara kredit. Yang demikian itu bukanlah tujuan jual beli.

Term hilah dalam fiqh diidentifikasikan sebagai upaya mencari legitimasi hukum untuk suatu kepentingan dengan tujuan-tujuan ekstra. Tujuan ekstra dalam konteks tersebut diartikan sebagai kepentingan khusus yang tidak memiliki kaitan langsung dengan hakikat aturan yang ditentukan oleh hukum syariat. Dalam kasus murabahah ini kadang pembeli membeli barang atau sesuatu untuk memanfaatkannya dan kadang membeli barang untuk menjualnya kembali (seperti Bank Islam), kedua hal ini dibolehkan, namun kadang pembeli bermaksud untuk mengambil riba. Dengan demikian tergantung niat dari pembeli tersebut, sebagaimana ditegaskan dalam Hadis Nabi SAW :

"Sesungguhnya amal perbuatan itu berdasarkan niyatnya".

Pendapat kedua, murabahah merupakan jual beli inah. Inah berarti pinjaman. Seorang pedagang menjual barangnya dengan harga kredit, kemudian barangnya itu dibelinya lagi dari debitur dengan harga lebih 
murah. Rafi Yunus mengatakan bahwa jual beli inah adalah seorang menjual sesuatu kepada orang lain dengan harga bertempo, lalu sesuatu itu diserahkan kepada pihak pembeli, kemudian penjual itu membeli kembali barangnya tadi sebelum harganya diterima dengan harga yang lebih rendah daripada harga jualnya tadi. Tidaklah dibenarkan menjual sesuatu dengan harga kredit atau membeli dari pembelinya secara kontan dengan harga lebih murah sebelum penjual pertama menerima pembayarannya. Karena kalau yang dimaksud untuk berdalih agar dapat menerima barang seketika dan menjualnya dengan harga yang lebih mahal beberapa hari kemudian, maka tidak diragukan bahwa perbuatan semacam ini adalah riba. Pendapat ketiga, murabahah adalah bai' atanai fi bai'ah. Ibnu Ruslan dalam syarah as-Sunan menafsirkan bahwa bai' atani fi bai'ah adalah seseorang meminjamkan satu dinar kepada orang lain selama sebulan dengan ketentuan dibayar satu takar gandum. Kemudian setelah datang waktu yang ditentukan dan gandum itu telah dimintanya, maka orang yang meminjam itu berkata:

"jualan gandum ini kepada saya dengan tempo pembayaran selama dua bulan yang akan saya bayar dengan dua takar".

Pendapat keempat, murabahah adalah jual beli barang yang belum dimiliki. Al-Baghawi berkata: termasuk jual beli yang fasid ialah menjual sesuatu yang belum dimiliki, misalnya menjual burung yang lepas tidak ada harapan pulang kembali ke tempatnya.

Jadi Murabahah adalah salah satu produk yang dikembangkan oleh bank syari'ah. Produk ini di dasarkan pada prinsip jual beli yang dalam istilah fiqh Islam disebut dengan bai' al-murabahah sebagaimana didefinisikan oleh ulama fiqh adalah menjual barang dengan harga pokok ditambah dengan keuntungan yang disepakati oleh kedua belah pihak. Bai' al-murabahah ini merupakan salah satu bentuk bai' al-amanah, disamping bai' at-tauliyyah, yakni menjual barang dengan harga pokok tanpa mengambil keuntungan apapun dan bai'al-wadhi'ah, yakni menjual barang dengan harga jual dibawah harga pokok. Bai' al-murabahah dalam fiqh kemudian diterapkan dalam bentuk produk perbankan syari'ah. Dalam perbankan syari'ah, produk ini diartikan sebagai akad jual beli antara bank selaku penyedia barang dengan nasabah yang memesan untuk membeli barang. Dari transaksi tersebut, bank mendapatkan keuntungan.

\section{Pembiayaan Murabahah Berdasarkan Hukum Positif}

Murabahah merupakan salah satu produk atau skim yang paling populer dalam praktek pembiayaan pada perbankan syariah. Selain mudah perhitungannya, baik bagi nasabah, maupun manajemen bank, produk ini memilki beberapa kesamaan (yang bukan prinsipil) dengan sistem kredit pada perbankan konvensional. Meskipun demikian, secara prinsip, 
murabahah sangat jauh berbeda dengan suku bunga dalam perbankan konvensional.

Dapat diartikan bahwa murabahah itu sebagai suatu perjanjian antara bank dan nasabah dalam bentuk pembiayaan pembelian atas sesuatu barang yang dibutuhkan oleh nasabah. Kata murabahah ini dari kata ribhu (keuntungan), yaitu transaksi jual beli di mana bank menyebut jumlah keuntungannya. Bank bertindak sebagai penjual sementara nasabah sebagai pembeli. Harga jual adalah harga beli bank dari pemasok ditambah keuntungan (margin).

Penjelasan atas Pasal 19 ayat (1) huruf d Undang-Undang Nomor 21 Tahun 2008 menjelaskan bahwa:

"Yang dimaksud dengan akad murabahah adalah akad pembiayaan suatu barang dengan menegaskan harga belinya kepada pembeli dan pembeli membayarnya dengan harga yang lebih sebagai keuntungan yang disepakati”.

Jadi, fitur mekanisme pembiayaan murabahah adalah penyediaan dana atau tagihan yang dapat dipersamakan dengan itu untuk transaksi jual beli suatu barang sebesar harga pokok atau perolehan ditambah dengan margin keuntungan yang disepakati antara bank dan nasabah yang mewajibkan nasabah untuk melunasi utang atau membayar tagihan sesuai dengan akad, dimana sebelumnya menginformasikan harga perolehan kepada pembeli.

Pembiayaan murabahah ini secara prinsip merupakan saluran penyalur dana bank syariah dengan cepat dan mudah, di mana bank syariah mendapat profit, yaitu margin dari pembiayaan serta mendapatkan fee based in come (administrasi, komisi asuransi, dan komisi notaris). Sementara bagi nasabah, pembiayaan murabahah ini merupakan alternatif pendanaan yang memberikan keuntungan kepada nasabah dalam bentuk membiayai kebutuhan nasabah dalam hal pengadaan barang, seperti pembelian dan renovasi bangunan, pembelian kendaraan, pembelian barang produktif seperti mesin produksi, dan pengadaan barang lainnya. Di sini nasabah akan mendapat peluang mengangsur pembayarannya dengan jumlah angsuran tidak akan berubah selama masa perjanjian.

Adapun risiko utama dari produk pembiayaan murabahah ini adalah risiko pembiayaan (credit risk) yang terjadi jika debitur wanprestasi atau default. Selain itu, risiko pasar juga dapat terjadi jika pembiayaan murabahah diberikan dalam valuta asing, yaitu risiko dari pergerakan nilai tukar. Murabahah adalah transaksi (trustworhiness) sebab pembeli telah mempercayakan penjual untuk menentukan harga asal barang yang dibelinya. Oleh karena itu, ketika bank menawarkan skim pembiayaan murabahah, maka sebenarnya bank menawarkan kepercayaan dari goodwill yang tinggi kepada nasabah, dan sebaliknya nasabah juga memberikan 
kepercayaan yang penuh kepada pihak bank. Konsep amanah dan saling memercayai inilah yang membedakan murabahah dengan pinjaman yang berbasiskan bunga tetap.

Seperti diketahui bahwa pembiayaan murabahah adalah jual beli barang pada harga asal dengan tambahan keuntungan/margin yang disepakati. Dalam jual beli ini, penjual harus tahu harga pokok pembelian barang dan menentukan tingkat tertentu sebagai tambahan dan menjelaskannya kepada pembeli. Murabahah menekankan adanya pembelian komoditas berdasarkan pemintaan nasabah, bukan hanya pinjaman semata sebagaimana dalam sistem kredit di perbankan konvensional. Dalam praktek pembiayaan murabahah, nasabah datang mengajukan pembiayaan atas sebuah komoditas dengan kriteria tertentu. Pada tahap ini terjadi negoisasi dan penyertaan yang harus dipenuhi oleh kedua belah pihak. Kemudian, bank memesan barang kepada supplier sesuai dengan kriteria yang diinginkan nasabah. Setelah barang tersebut resmi menjadi milik bank, baru kemudian terjadi kontrak jual beli antara nasabah dan pihak bank. Barang dan dokumen dikirimkan kepada nasabah, kemudian nasabah melakukan pembayaran sesuai dengan kesepakatan. Dengan demikian, jika melihat praktek pembayaran murabahah, tidak ditemukan adanya unsur bunga, hanya margin sebagai tambahan atas harga pokok pembelian sehingga tidak bertentangan dengan syariah.

Pembiayaan murabahah ini ditetapkan untuk perbankan syariah melalui Surat Keputusan Direksi Bank Indonesia Nomor 32/34/Kep/Dir tentang Bank Umum berdasarkan Prinsip Syariah, yang kemudian diperbaharui dengan Peraturan Bank Indonesia Nomor 6/24/PBI/2004 tentang Bank Umum yang melaksanakan Kegiatan Usaha Berdasarkan Prinsip Syariah sebagaimana telah diubah dengan Peraturan Bank Indonesia Nomor 7/35/PBI/2005 dan Surat Keputusan Direksi Bank Indonesia Nomor 32/36/Kep/PBI/Dir tentang Bank Perkreditan Rakyat Berdasarkan Prinsip Syariah, yang kemudian diperbaharui dan disempurnakan dengan Peraturan Bank Indonesia Nomor 6/17/PBI/2004 tentang Bank Perkreditan Rakyat Berdasarkan Prinsip Syariah sebagaiamana telah dirubah dengan Peraturan Bank Indoneisa Nomor 8/25/PBI/2006. Selanjutnya ditegaskan kembali dalam Undang-Undnag Nomor 21 Tahun 2008 tentang Perbankan Syariah.

\section{Pembiayaan Murabahah Berdasarkan Fatwa Nomor 04/DSN- MUI/IV/2000 Jo Komplikasi Hukum Ekonomi Syariah}

Berkenaan dengan pembiayaan murabahah dalam kegiatan perbankan syariah, DSN telah mengeluarkan Fatwa Nomor 04/DSN-MUI/IV/2000 tentang murabahah yang menetapkan pedoman bagi bank syariah yang memiliki fasilitas murabahah dan ditegaskan kembali dalam Komplikasi Hukum Ekonomi Syariah. Adapun ketentuan tentang pembiayaan 
murabahah yang telah dirumuskan DSN dalam Fatwanya Nomor 04/DSNMUI/IV/2000 sebagai berikut:

a. ketentuan umum murabahah dalam bank syariah:

1) bank dan nasabah harus melakukan akad murabahah yang bebas riba;

2) barang yang diperjualbelikan tidak diharamkan oleh syariat Islam;

3) bank membiayai sebagian atau seluruh harga pembelian barang yang telah disepekati kualifikasinya;

4) bank membeli barang yang diperlukan nasabah atas nama bank sendiri dan pembelian ini harus sah dan bebas riba;

5) bank harus menyampaikan semua hal yang harus berkaitan dengan pembelian, misalnya, jika pembelian dilakukan secara utang;

6) bank kemudian menjual barang tersebut kepada nasabah (pemesan) dengan harga jual senilai harga beli ditambah keuntungannya. Dalam kaitan ini bank harus memberi tahu secara jujur harga pokok barang kepada nasabah;

7) nasabah membayar harga barang yang telah disepakati tersebut pada jangka waktu tertentu yang telah disepakati;

8) untuk mencegah terjadinya penyalahgunaan atau kerusakan tersebut, pihak bank dapat mengadakan perjanjian khusus dengan nasabah; dan

9) jika bank berkehendak mewakilkan kepada nasabah untuk membeli barang dari pihak ketiga, akad jual beli murabahah harus dilakukan setelah barang, secara prinsip menjadi milik bank.

Sedangkan berdasarkan ketentuan Pasal 107 Komplikasi Hukum Islam menyatakan dalam hal jual beli murabahah berlaku ketentuan:

1) penjual harus membiayai sebagian atau seluruh harga pembelian barang yang telah disepakati kualifikasinya;

2) penjual harus membeli barang yang diperlukan pembeli atas nama penjual sendiri, dan pembelian harus sah dan bebas riba;

3) penjual harus menyampaikan semua hal yang berkaitan dengan pembelian;

4) penjual harus memberi tahu secara jujur harga pokok barang kepada pembeli berikut biaya yang diperlukan; dan

5) pembeli harus membayar harga barang yang telah disepakati tersebut pada jangka waktu tertentu yang telah disepakati pula.

b. ketentuan murabahah kepada nasabah:

1) nasabah mengajukan permohonan dan perjanjian pembelian suatu barang atau aset kepada bank;

2) jika bank menerima permohonan tersebut, ia harus membeli terlebih dahulu aset yang dipesannya secara sah dengan perdagangan;

3) bank kemudian menawarkan aset tersebut kepada nasabah dan nasabah harus menerima (membelinya) sesuai dengan perjanjian yang telah 
disepakatinya, karena secara hukum perjanjian tersebut mengikat, kemudian kedua belah pihak harus membuat kontrak jual beli;

4) dalam jual beli ini bank diperbolehkan meminta nasabah untuk membayar uang di muka saat menandatangani kesepakatan awal pemesanan. Hal ini lazim disebut dengan bai'arbun. Menurut jumhur ulama, hal ini memang tidak diperbolehkan. Namun, jika berdasar pada pendapat Imam Ahmad bin Hambal, jual beli 'urbun diperbolehkan. Jika nasabah memutuskan untuk membeli komoditas tersebut, uang muka tersebut bisa digunakan sebagai pengurangan atas harga yang disepakati;

5) jika nasabah kemudian menolak membeli barang tersebut, biaya riil bank harus dibayar dari uang muka tersebut;

6) jika nilai uang muka kurang dari kerugian yang harus ditanggung oleh bank, bank dapat meminta kembali sisa kerugiannya kepada nasabah; dan

7) jika uang muka memakai kontrak 'urbun sebagai alternatif dari uang muka, maka:

a) jika nasabah memutuskan untuk membeli barang tersebut, ia tinggal membayar sisa harga; dan

b) jika nasabah batal membeli, uang muka menjadi milik bank maksimal sebesar kerugian yang ditanggung oleh bank akibat pembatalan tersebut dan jika uang muka tidak mencukupi, nasabah wajib melunasi kekurangannya.

c) jaminan dalam murabahah:

a. jaminan dalam murabahah dibolehkan, agar serius dengan pesanannya. Bank boleh meminta jaminan yang bernilai ekonomis dan sesuai dengan jumlah transaksi yang dilakukan sebagai pegangan. Jaminan itu muncul karena jual beli yang dilakukan adalah secara tempo sehingga dirasa perlu untuk menghadirkan jaminan; dan

b. bank dapat meminta nasabah untuk menyediakan jaminan yang dapat dipegang.

d) utang dalam murabahah:

a. secara prinsip, penyelesaian utang nasabah dalam transaksi murabahah tidak ada kaitannya dengan transaksi lain yang dilakukan nasabah dengan pihak ketiga atas barang tersebut. Jika nasabah menjual kembali barang tersebut dengan keuntungan atau kerugian, ia tetap berkewajiban untuk menyelesaikan utangnya kepada bank;

b. jika nasabah menjual barang tersebut sebelum masa angsuran berakhir, ia tidak wajib, segera seluruh angsurannya; dan 
c. jika penjualan barang tersebut menyebabkan kerugian, nasabah tetap harus menyelesaikan utangnya sesuai kesepakatan awal. Ia tidak boleh memperlambat pembayaran angsuran atau meminta kerugian itu diperhitungkan.

e) Penundaan pembayaran dalam murabahah:

a. nasabah yang memiliki kemampuan tidak dibenarkan menunda penyelesaian utangnya; dan

b. jika nasabah menunda-nunda pembayaran dengan sengaja atau jika salah satu pihak tidak menunaikan kewajibannya, penyelesaiannya dilakukan melalui badan arbitrase syariah setelah tidak tercapai kesepakatan melalui musyawarah.

f) bangkrut dalam murabahah

jika nasabah telah dinyatakan pailit dan gagal menyelesaikan utangnya, bank harus menunda tagihan utang sampai ia menjadi sanggup kembali atau berdasarkan kesepakatan.

\section{Penutup}

\section{Kesimpulan}

a. Bahwa Murabahah adalah salah satu produk yang dikembangkan oleh bank syari'ah. Produk ini di dasarkan pada prinsip jual beli yang dalam istilah fiqh Islam disebut dengan bai' al-murabahah sebagaimana diidefinisikan oleh ulama fiqh adalah menjual barang dengan harga pokok ditambah dengan keuntungan yang disepakati oleh kedua belah pihak. Bai' al-murabahah ini merupakan salah satu bentuk bai' al-amanah, disamping bai' at-tauliyyah, yakni menjual barang dengan harga pokok tanpa mengambil keuntungan apapun dan bai'al-wadhi'ah, yakni menjual barang dengan harga jual di bawah harga pokok. Bai' al-murabahah dalam fiqh kemudian diterapkan dalam bentuk produk perbankan syariah. Dalam perbankan syariah, produk ini diartikan sebagai akad jual beli antara bank selaku penyedia barang dengan nasabah yang memesan untuk membeli barang. Dari transaksi tersebut, bank mendapatkan keuntungan;

b. Pembiayaan murabahah berdasarkan hukum positif ditetapkan melalui Surat Keputusan Direksi Bank Indonesia Nomor 32/34/Kep/Dir tentang Bank Umum berdasarkan Prinsip Syariah, yang kemudian diperbaharui dengan Peraturan Bank Indonesia Nomor 6/24/PBI/2004 tentang Bank Umum yang melaksanakan Kegiatan Usaha Berdasarkan Prinsip Syariah sebagaimana telah diubah dengan Peraturan Bank Indonesia Nomor 7/35/PBI/2005 dan Surat Keputusan Direksi Bank Indonesia Nomor 32/36/Kep/PBI/Dir tentang Bank Perkreditan Rakyat Berdasarkan Prinsip Syariah, yang kemudian diperbaharui dan disempurnakan dengan Peraturan Bank Indonesia Nomor 6/17/PBI/2004 tentang Bank Perkreditan Rakyat Berdasarkan Prinsip Syariah sebagaimana telah 
dirubah dengan Peraturan Bank Indoneisa Nomor 8/25/PBI/2006. Selanjutnya ditegaskan kembali dalam Undang-Undang Nomor 21 Tahun 2008 tentang Perbankan Syariah; dan

c. berkenaan dengan pembiayaan murabahah dalam kegiatan perbankan syariah, DSN (Dewan Syariah Nasional) telah mengeluarkan Fatwa Nomor 04/DSN-MUI/IV/2000 tentang murabahah yang menetapkan pedoman bagi bank syariah yang memiliki fasilitas murabahah dan ditegaskan kembali dalam Komplikasi Hukum Ekonomi Syariah dengan ketentuan umum dalam pembiayaan murabahah adalah Bank dan nasabah harus melakukan akad murabahah yang bebas riba dan barang yang diperjualbelikan tidak diharamkan oleh syariah Islam.

\section{Daftar Pustaka}

\section{A. Buku}

Az-Zuhaili, Wahbah, 1989. al-Fiqh al-Islam wa Adillatuh, Jilid IV, Beirut: Dar al-Fikr, 1989.

Hadi, Abu Sura'i Abdul, 1993. Ar-Riba wa al-Qurudh, Al-Ikhlas, Surabaya: Terj. M. Thalib.

Harum, Ubay, Murabahah Dalam Perspektif Fiqh dan Sistem Perbankan Islam, Jurnal Hukum Islam, Vol V, 2006.

Karim, Adiwarman A., 2006. Bank Islam: Analisis Fiqh dan Keuangan, Jakarta: PT Raja Grafindo Persada.

Lubis, Suhrawardi K., 2000. Hukum Ekonomi Islam, Jakarta: Sinar Grafika.

Munawwir, Ahmad Warson, 1997. Kamus Arab-Indonesia, Cet. IV, Surabaya: Pustaka Progressif.

Penyusun, Ensiklopedi Hukum Islam, Ensiklopedia Hukum Islam, Jilid 1, Jakarta: PT Ichtiar Baru van Hoeve.

Sabiq, As-Sayyid, Fiqh As-Sunnah, Jilid III, (Beirut: Dar al-Fikr, t.t).

Saeed, Abdullah, 2003. Bank Islam dan Bunga, Studi Kritis dan Interpretasi Kontemporer tentang Riba dan Bunga, Yogyakarta: Pustaka Pelajar Terj. Muhammad Ufuqul Mubin, et. al, Cet. I.

Schacht, 1986. The Encyclopedia of Islam, Leiden: E.J. Brill.

Sutedi, Adrian, 2009. Perbankan Syariah, Bogor: Ghalia Indonesia,.

Usman, Rachmadi, 2009. Produk dan Akad Perbankan Syariah Di Indonesia, Bandung: PT Citara Aditya.

\section{B. Peraturan Perundang-Undangan}

Undang-Undang Dasar Negara Republik Indonesia Tahun 1945.

Undang-Undang Nomor 21 Tahun 2008 tentang Perbankan Syariah. 
Undang-undang No. 10 Tahum 1998 tentang Perbankan

Peraturan Bank Indonesia Nomor 7/46/PBI/2005 tentang Akad Penghimpunan dan Penyaluran Dana bagi bank yang melaksanakan Kegiatan Usha Berdasarkan Prinsip Syariah.

Peraturan Bank Indonesia nomor 6/17/PBI/2004 tentang Bank Perkreditan Rakyat Berdasarkan Prinsip Syariah sebagaimana telah dirubah dengan Peraturan Bank Indoneisa Nomor 8/25/PBI/2006.

Surat Keputusan Direksi Bank Indonesia Nomor 32/34/Kep/Dir tentang Bank umum berdasarkan Prinsip Syariah.

Surat Keputusan Direksi Bank Indonesia Nomor 32/36/Kep/PBI/Dir tentang Bank Perkreditan Rakyat Berdasarkan Prinsip Syariah.

Fatwa Nomor 04/DSN-MUI/IV/2000 tentang murabahah.

Komplikasi Hukum Ekonomi Syariah.

C. Sumber Lain

Al-Bukhari, Shahih al-Bukhari, (CD Hadits). 